\title{
Effect of Extraction Conditions on the Phenolic Content and DPPH Radical Scavenging Activity of Hypericum perforatum $\mathrm{L}$.
}

\author{
Fadime Seyrekoğlu, ${ }^{1, a, *}$, Hasan Temiz ${ }^{2, b}$ \\ ${ }^{1}$ Department of Food Processing, Suluova Vocational Schools, Amasya University, 05500 Amasya, Turkey \\ ${ }^{2}$ Department of Food Engineering, Faculty of Engineering, Ondokuz Mayls University, 55270 Samsun, Turkey \\ *Corresponding author

\begin{tabular}{|c|c|}
\hline A R T I C L E I N F O & A B S T R A C T \\
\hline $\begin{array}{l}\text { Received : 03/10/2019 } \\
\text { Accepted : 01/11/2019 }\end{array}$ & $\begin{array}{l}\text { In this study, various extracts of Hypericum perforatum L. were investigated in terms of their } \\
\text { extraction yields. For this purpose, five solvent systems including } 70 \% \mathrm{EtOH}-30 \% \mathrm{H}_{2} \mathrm{O}(\mathrm{A}) \text {, } \\
50 \% \mathrm{EtOH}-50 \% \mathrm{H}_{2} \mathrm{O}(\mathrm{B}), 30 \% \mathrm{EtOH}-70 \% \mathrm{H}_{2} \mathrm{O}(\mathrm{C}), 100 \% \mathrm{EtOH}(\mathrm{D}) \text {, and } 100 \% \mathrm{H}_{2} \mathrm{O}(\mathrm{E}) \text { were used. } \\
\text { Ultrasonic-assisted extraction was used for extraction and extraction processes were performed at } \\
\text { different temperatures }\left(30^{\circ}-70^{\circ} \mathrm{C}\right) \text { and extraction times }(30-70 \text { min.). The optimum extraction } \\
\text { conditions for } \mathrm{H} \text {. perforatum was determined based on extraction yield, total phenolic contents, and } \\
\text { DPPH radical scavenging activities of the crude extracts, as well. The best ultrasound extraction } \\
\text { conditions are achieved in the presence of } 70 \% \mathrm{EtOH}-30 \% \mathrm{H}_{2} \mathrm{O} \text { solvent system, for } 40 \mathrm{~min} \text {, at } 30^{\circ} \mathrm{C} \\
\text { for } \mathrm{H} \text {. perforatum. }\end{array}$ \\
\hline
\end{tabular} \\ Keywords
}

St. John's Wort

Hypericum perforatum

Solvent

Extraction temperature

Optimum condition.

fadime.tokatli@amasya.edu.tr

(D) https://orcid.org/0000-0001-9787-4115

|b@hasant@omu.edu.tr (iD) https://orcid.org/0000-0003-3586-336X

\section{Introduction}

Bioactive compounds have gained interest in recent years due to their health beneficial effects in nutraceuticals and functional foods (Sevindik, 2019). Therefore, recent studies focused on the extraction of bioactive compounds from plants, determination of its biological activity, and utilization of the active extracts in food industry and pharmaceutical industries, as well (Aguilar-Garcia et al., 2007; Teixeira et al., 2014; Sevindik et al., 2017; Mohammed et al., 2019). Some medicinal and aromatic plants contain bioactive compounds such as antimicrobial, antioxidant, anti-inflammatory, anti- septic, anticarcinogenic, anti- viral, anti- allergic, as well (Sevindik et al., 2017). Antioxidant compounds protect the cell from the oxidative damage via preventing the increase of free radicals, and antioxidants can stabilize the free radical levels after damage (Sevindik, 2019). Thus, these plants are used as antioxidant sources to reduce oxidative damage (Sevindik et al., 2017). The use of alternative medicinal and aromatic plants contributes to the socio- economic life in developing countries. Additionally, these herbal products are used for personal care related purposes such as healthy nutrition, healthy food supplements, and herbal teas (Mohammed et al., 2019).

The yield of secondary metabolite extraction has great importance especially for food industry. Therefore, it is important to determine the optimum extraction conditions for the targeted secondary metabolite in order to obtain high efficiency. Tahmasebi-Boldagi et al. optimized the extraction of hypericin from Hypericum perforatum L. using ultrasound assisted extraction method (TahmasebiBoldagi et al., 2019).

Optimization of the crude polysaccharides from $H$. perforatum was performed by Heydarian et al. (Heydarian et al., 2017). Another study was carried out by Akalin et al. including extraction of medicinal compounds from $H$. perforatum using supercritical fluid extraction method (Akalin et al., 2014). Soxhlet extraction and solid phase extraction (SPE) of hypericin from $H$. perforatum was investigated by Cossuta et al. (Cossuta et al., 2009). 
The Hypericum genus has approximately 500 species all over the World. $H$. perforatum has been generally studied due to its biological activities including antitumor, antimicrobial, antiviral, and antidepressant (Ramezani and Zamani, 2017). Hypericum species have been used in traditional medicine for skin injuries and burns in public, as well (Dresler et al., 2018). The curative properties of medicinal plants mainly depend on the phytochemical contents of the plants (Chuen et al. 2016; Ben Jannet et al. 2017). $H$. perforatum contains flavonoids, phloroglucinocontals, naphthodianthrones, phenolic acids and essential oil, as well (Dresler et al., 2018).

Appropriate and standardized extraction techniques need to be adopted in order to enhance effective use of plants. Therefore, the present study focused on the determination of optimum extraction conditions for $H$. perforatum using ultrasound extraction technique. For this purpose, various extraction solvent systems, temperatures, and extraction times were studied in order to obtain the highest total phenolic content and DPPH radical scavenging activities, as well.

\section{Material and Method}

\section{Plant Material}

Aerial parts of $H$. perforatum were collected during June and August 2018 from Amasya. Identification of the plant material was performed by Dr. Cengiz Yildirim (Amasya University, Faculty of Education, Amasya, Turkey) using Flora of Turkey (vol 2) (Davis, 1967). The plant material was dried in shadow, at room temperature.

\section{Extraction Procedure}

The dried and grounded plant material was extracted with EtOH- $\mathrm{H}_{2} \mathrm{O}$ solvent system with different concentrations. Ultrasonic-assisted extraction was used for the extraction processes. Different parameters (temperature, extraction time, extraction solvent) were studied in order to determine optimum conditions for $H$. perforatum extraction. Determination of the optimum conditions was performed using the following factors: solvent system A (EtOH 70\% $\left.\mathrm{H}_{2} \mathrm{O} 30 \%\right)$, B (EtOH 50\% - $\left.\mathrm{H}_{2} \mathrm{O} 50 \%\right), \mathrm{C}\left(\mathrm{EtOH} 30 \%-\mathrm{H}_{2} \mathrm{O}\right.$ $70 \%), \mathrm{D}(\mathrm{EtOH} 100 \%)$, and $\mathrm{E}\left(\mathrm{H}_{2} \mathrm{O} 100 \%\right)$; extraction temperature $\left(30,40,50,60\right.$, and $\left.70^{\circ} \mathrm{C}\right)$; extraction time $(30$, $40,50,60$, and $70 \mathrm{~min}$ ). The minimum and maximum values of variables are determined according to literature results. After the evaporation process of the solvents, total phenolic contents and DPPH radical scavenging activities of the extracts were detected.

\section{Total Phenolic Content}

Phenolic contents of the extracts were carried out following the method of Singleton and Rossi (1965). For this purpose, the samples $(40 \mu \mathrm{L}$, triplicates $)$ were introduced into test tubes; $2.4 \mathrm{~mL}$ distilled water and 200 $\mu \mathrm{L}$ Folin-Ciocalteau were added. After $30 \mathrm{sec}$., saturated
$\mathrm{Na}_{2} \mathrm{CO}_{3}(600 \mu \mathrm{L})$ and distilled water $(760 \mu \mathrm{L})$ were added into the tubes. The tubes were shaken vigorously and incubated for $2 \mathrm{~h}$. Finally, the samples were tested spectrophotometrically at $650 \mathrm{~nm}$. The results were expressed as $\mathrm{g} / \mathrm{kg}$ GAE using the calibration graphic of gallic acid $(\mathrm{y}=0,001 \times+0,014)$.

\section{DPPH Free Radical Scavenging Activity}

The methodology of Singh et al. (2002) was used in order to determine the DPPH free radical scavenging capacity of the samples. Briefly, $0.1 \mathrm{mM}$ solution of DPPH was prepared in methanol and $3.8 \mathrm{~mL}$ of this solution was added to $200 \mu \mathrm{L}$ of the samples. The solutions were vortexed properly and incubated in dark for $60 \mathrm{~min}$, at room temperature. The absorbance was measured at 515 $\mathrm{nm}$ against blank samples. The test was applied in triplicate. Lower absorbance of the reaction mixture shows that higher DPPH free radical scavenging activity. The capability to scavenge DPPH radicals was calculated using the following equation:

$$
\text { DPPH scavenging effect }(\%)=(1-\mathrm{AS} / \mathrm{AC}) \times 100
$$

where AC is the absorbance of the control which contains DPPH solution and AS is the absorbance in the presence of the samples (Demirtas et al., 2010). The results were expressed as $\mathrm{IC}_{50}$ values.

\section{Statistical Analysis}

The research was conducted using a factorial design with yield, total antioxidant and total phenolic as the three factors. All analyses were performed with SPSS software version 16 (SPSS Inc., Chicago, IL, USA). Means were compared by Tukey's test and differences at $\mathrm{P}<0.05$ were considered significant.

\section{Results and Discussion}

\section{Determination of The Optimum Solvent System}

Optimum conditions for $H$. perforatum extraction were carried out based on the results of total phenolic amount and DPPH radical scavenging activity, as well.

Effect of solvent system on the total phenolic content and DPPH activity was given in Table 1 . For determination of the optimum solvent system, three parameters (yield, total phenolic content, and $\mathrm{IC}_{50}$ value) were evaluated together. Lower $\mathrm{IC}_{50}$ value indicates higher free radical scavenging activity. According to this, the highest radical scavenging activity was obtained with EtOH $100 \%$ solvent system, followed by EtOH $30 \%-\mathrm{H}_{2} \mathrm{O} 70 \%$ and $\mathrm{H}_{2} \mathrm{O} 100 \%$. On the other hand, total phenolic amount of the EtOH $100 \%$ solvent system extract was found as $255.69 \mathrm{~g} / \mathrm{kg}$ GAE. The highest total phenolic content was obtained as $265.43 \mathrm{~g} / \mathrm{kg}$ GAE with EtOH $70 \%-\mathrm{H}_{2} \mathrm{O} 30 \%$ solvent system.

Table 1 Effect of solvent system on the total phenolic content and DPPH activity

\begin{tabular}{|c|c|c|c|}
\hline Sample & Yield $(\%)$ & Total Phenolic Content (g/kg GAE) & $\mathrm{IC}_{50}$ \\
\hline $\mathrm{A}$ & $6.986^{\mathrm{c}} \pm 0.005$ & $265.43^{\mathrm{a}} \pm 0.378$ & $124.478^{\mathrm{b}} \pm 0.020$ \\
\hline B & $6.690^{\mathrm{d}} \pm 0.010$ & $262.50^{\mathrm{b}} \pm 0.100$ & $171.377^{\mathrm{a}} \pm 0.005$ \\
\hline $\mathrm{C}$ & $9.731^{b} \pm 0.002$ & $249.20^{\mathrm{d}} \pm 0.100$ & $66.116^{\mathrm{d}} \pm 0.005$ \\
\hline $\mathrm{D}$ & $1.361^{\mathrm{e}} \pm 0.002$ & $255.69^{c} \pm 0.085$ & $63.526^{\mathrm{e}} \pm 0.023$ \\
\hline $\mathrm{E}$ & $9.938^{\mathrm{a}} \pm 0.002$ & $233.83^{\mathrm{e}} \pm 0.028$ & $66.430^{c} \pm 0.000$ \\
\hline
\end{tabular}

*A (EtOH 70\% - $\left.\mathrm{H}_{2} \mathrm{O} 30 \%\right), \mathrm{B}\left(\mathrm{EtOH} 50 \%-\mathrm{H}_{2} \mathrm{O} 50 \%\right), \mathrm{C}\left(\mathrm{EtOH} 30 \%-\mathrm{H}_{2} \mathrm{O} 70 \%\right), \mathrm{D}(\mathrm{EtOH} 100 \%), \mathrm{E}\left(\mathrm{H}_{2} \mathrm{O} 100 \%\right)$; Extraction temperature (T): $30^{\circ} \mathrm{C}$; Extraction time (t): 30 min; Material-Liquor ratio (M:L): 1:30; (P>0.05). 
Table 2 Effect of temperature on the total phenolic content and DPPH activity

\begin{tabular}{c|ccc}
\hline Temp. $\left({ }^{\circ} \mathrm{C}\right)$ & Yield $(\%)$ & Total Phenolic Content $(\mathrm{g} / \mathrm{kg} \mathrm{GAE})$ & $\mathrm{IC}_{50}$ \\
\hline 30 & $2.500^{\mathrm{e}} \pm 0.010$ & $225.967^{\mathrm{e}} \pm 0.152$ & $78.546^{\mathrm{b}} \pm 0.005$ \\
40 & $3.510^{\mathrm{d}} \pm 0.010$ & $314.400^{\mathrm{c}} \pm 0.264$ & $100.003^{\mathrm{a}} \pm 0.005$ \\
50 & $4.256^{\mathrm{c}} \pm 0.005$ & $304.167^{\mathrm{d}} \pm 0.057$ & $100.003^{\mathrm{a}} \pm 0.005$ \\
60 & $4.566^{\mathrm{b}} \pm 0.005$ & $330.567^{\mathrm{b}} \pm 0.057$ & $100.007^{\mathrm{a}} \pm 0.005$ \\
70 & $5.716^{\mathrm{a}} \pm 0.005$ & $392.167^{\mathrm{a}} \pm 0.057$ & $100.010^{\mathrm{a}} \pm 0.000$ \\
\hline
\end{tabular}

*Extraction solvent: EtOH 30\% - $\mathrm{H}_{2} \mathrm{O} 70 \%$; Extraction time (t): 30 min; Material-Liquor ratio (M:L): 1:30; (P>0.05).

Table 3 Effect of extraction time on the total phenolic content and DPPH activity

\begin{tabular}{c|ccr}
\hline Extraction time (min) & \multicolumn{1}{c}{ Yield (\%) } & Total Phenolic Content (g/kg GAE) & \multicolumn{1}{c}{$\mathrm{IC}_{50}$} \\
\hline 30 & $9.046^{\mathrm{e}} \pm 0.005$ & $253.367^{\mathrm{c}} \pm 0.057$ & $100.100^{\mathrm{a}} \pm 0.100$ \\
40 & $11.413^{\mathrm{d}} \pm 0.005$ & $256.867^{\mathrm{b}} \pm 0.808$ & $82.576^{\mathrm{c}} \pm 0.005$ \\
50 & $13.760^{\mathrm{c}} \pm 0.010$ & $262.567^{\mathrm{a}} \pm 0.057$ & $100.003^{\mathrm{a}} \pm 0.005$ \\
60 & $14.376^{\mathrm{b}} \pm 0.005$ & $238.033^{\mathrm{e}} \pm 0.057$ & $98.770^{\mathrm{b}} \pm 0.060$ \\
70 & $15.006^{\mathrm{a}} \pm 0.005$ & $243.367^{\mathrm{d}} \pm 0.057$ & $100.033^{\mathrm{a}} \pm 0.057$ \\
\hline
\end{tabular}

*Extraction solvent: EtOH 30\% - $\mathrm{H}_{2} \mathrm{O} 70 \%$; Extraction temperature (T): 30 ${ }^{\circ} \mathrm{C}$; Material-Liquor ratio (M:L): 1:30; (P>0.05).

Many factors affect the variation between the total phenolic content and the antioxidant activity. Generally, antioxidant activity of the extracts/compounds are correlated with the total phenolic content. On the other hand, synergism and structures of the compounds play important role for determination of antioxidant activity. Thus, it must be taken into account the synergism between the antioxidants in the mixture that makes the antioxidant activity not only dependent on the concentration, but also on the structure and the interaction between the antioxidants. This can explain why samples with similar concentration of total phenolics, vary in their antioxidant activities (DPPH) (Piluzza and Bullitta, 2011). Therefore, yield of the extracts were taken into account for evaluation of the optimum parameters for $H$. perforatum extraction. EtOH $100 \%$ solvent system gave the highest DPPH activity while it has the lowest yield $(1.361 \%)$. So, the optimum solvent system was determined as EtOH $30 \%-$ $\mathrm{H}_{2} \mathrm{O} 70 \%$ in the result of evaluation of all data (Table 1). In agreement with other researchers (Cossuta et al., 2009; Ozturk et al., 2007; Schmitt et al., 2006), etanol-water solvent system was used for $H$. perforatum extraction, to produce an environmentally friendly and biologically active solvent system with high yield.

Effect of temperature on the total phenolic content, DPPH activity, and total yield was seen in Table 2. It can be seen from the Table 2 that total yield of the extracts increases with increasing temperature. Generally, total phenolic amount was found higher with higher temperatures. On the other hand, $\mathrm{IC}_{50}$ value of the extracts were not affected considerably above $40^{\circ} \mathrm{C}$. DPPH activity of the extracts gave the highest value at $30^{\circ} \mathrm{C}$. Thus, $30^{\circ} \mathrm{C}$ was determined as the optimum temperature, confirmed by the study of Milevskaya et al. (2015); related with extraction of the active components from $H$. perforatum using ultrasound extraction technique.

Finally, the optimum extraction time was determined based on the results of yield, total phenolic, and $\mathrm{IC}_{50}$ values, as well (Table 3). The highest DPPH activity value of the extracts was obtained with $40 \mathrm{~min}$. extraction. Additionally, experimental data show that the total phenolic amount of the extracts gave the highest value of $262,567 \mathrm{~g} / \mathrm{kg} \mathrm{GAE}$ at $50 \mathrm{~min}$. extraction which was closed to the value of $256.867 \mathrm{~g} / \mathrm{kg}$ GAE that was obtained with the optimum extraction time (40 min.). Although different results were obtained in the determination of the optimum extraction time (Table 3), the most important parameter ( $\mathrm{IC}_{50}$ values) for antioxidant activity were taken into consideration in the evaluation of Table 3 . The results were similar with the study of Ghiasvand et al. (2016). They performed extraction of $H$. perforatum using ultrasoundassisted technique and they obtained the best results with 40 min. extraction.

\section{Conclusion}

Extraction of natural compounds from plants is one of the first steps of plant related studies. It is important to determine optimum extraction conditions for plants in order to take advantage of targeted activity, natural compound, etc. In this study, different extraction conditions including extraction solvent, extraction time, and extraction temperature were screened based on total phenolic content and DPPH radical scavenging activities of $H$. perforatum plant, respectively. It is known that, antioxidant activities of the plants are generally correlated with their phenolic amounts and DPPH activities, as well. For $H$. perforatum plant, the best ultrasonic-assisted extraction conditions were obtained with $\mathrm{EtOH} 30 \%-\mathrm{H}_{2} \mathrm{O}$ $70 \%$ solvent system, at $30^{\circ} \mathrm{C}$, for $40 \mathrm{~min}$.

\section{References}

Aguilar-Garcia C, Gavino G, Baragano-Mosqueda M, Hevia P, Gavino VC. 2007. Correlation of tocopherol, tocotrienol, $\gamma$ oryzanol and total polyphenol content in rice bran with different antioxidant capacity assays. Food Chemistry, 102(4), 1228-1232.

Akalın MK, Karagöz S. 2014. Optimization of ethanol supercritical fluid extraction of medicinal compounds from St. John's Wort by central composite design. Analytical Letters, 47(11), 1900-1911.

Chuen TL, Vuong QV, Hirun S, Bowyer MC, Predebon MJ, Goldsmith CD, Scarlett CJ. 2016. Antioxidant and antiproliferative properties of Davidson's plum (Davidsonia pruriens F. Muell) phenolic-enriched extracts as affected by different extraction solvents. J Herb Med, 6: 187-192. 
Cossuta D, Vatai T, Bathori M, Hohmann J, Keve T, Simandi B. 2009. Extraction of Hyperforin from St John's Wort (Hypericum perforatum L.) with Different Solvents. Journal of Food Process Engineering, 35(2): 222-235.

Davis PH. 1967. Flora of Turkey and the East Aegean Islands Vol. 2: University Press, Edinburgh, pp. 355-401.

Demirtas B, Ayhan A, Sahin H, Aksit M, Elmastas and I Telci. 2010. Antioxidant activity and chemical composition of Sideritis libanotica Labill. ssp. linearis (Bentham) Borm. (Lamiaceae). Nat. Prod. Res., 25: 1512-1523.

Dresler S, Ková cik J, Strzemski M, Sowa I, Wójciak-Kosior M. 2018. Methodological aspects of biologically active compounds quantification in the genus Hypericum. Journal of Pharmaceutical and Biomedical Analysis, 155: 82-90.

Ghiasvand A, Shadabi S, Hajipour S, Nasirian A, Borzouei M, Hassani-Moghadam E, Hashemi P. 2015. Comparison of ultrasound-assisted headspace solid-phase microextraction and hydrodistillation for the identification of major constituents in two species of hypericum. Journal of chromatographic science, 54(2): 264-270.

Heydarian M, Jooyandeh H, Nasehi B, Noshad M. 2017. Characterization of Hypericum perforatum polysaccharides with antioxidant and antimicrobial activities: optimization based statistical modeling. International journal of biological macromolecules, 104: 287-293.

Jannet SB, Hymery N, Bourgou S, Jdey A, Lachaal M, Magné C, Ksouri R. 2017. Antioxidant and selective anticancer activities of two Euphorbia species in human acute myeloid leukemia. Biomed Pharmacother, 90: 375-385.

Milevskaya VV, Statkus MA, Temerdashev ZA, Kiseleva NV, Vernikovskaya NA. 2015. Methods for the extraction of biologically active substances from medicinal plants based on an example of St. John's wort components. Journal of analytical chemistry, 70(12): 1432-1440.

Mohammed FS, Daştan T, Sevindik M, Selamoglu Z. 2019. Antioxidant, antimicrobial activity and therapeutic profile of Satureja hortensis from Erzincan Province. Cumhuriyet T1p Dergisi 41(3): 558-562.
Öztürk N, Korkmaz S, Öztürk Y. 2007. Wound-healing activity of St. John's Wort (Hypericum perforatum L.) on chicken embryonic fibroblasts. Journal of ethnopharmacology, 111(1): 33-39.

Piluzza G, Bullitta S. 2011. Correlations between phenolic content and antioxidant properties in twenty-four plant species of traditional ethnoveterinary use in the Mediterranean area. Pharmaceutical biology, 49(3): 240-247.

Ramezani Z, Zamani M. 2017. A simple method for extraction and purification of hypericins from St John's wort. Jundishapur Journal of Natural Pharmaceutical Products, 12(1).

Schmitt LA, Liu Y, Murphy PA, Petrich JW, Dixon PM, Birt D. F. 2006. Reduction in hypericin-induced phototoxicity by Hypericum perforatum extracts and pure compounds. Journal of Photochemistry and Photobiology B: Biology, 85(2): 118130.

Sevindik M, Akgul H, Pehlivan M, Selamoglu Z. 2017. Determination of therapeutic potential of Mentha longifolia ssp. longifolia. Fresen Environ Bull. 26(7): 4757-4763.

Sevindik M. 2019. Wild Edible Mushroom Cantharellus cibarius as a Natural Antioxidant Food. Turkish Journal of Agriculture-Food Science and Technology 7(9): 1377-1381.

Singh RP, Murthy KNC, Jayaprakasha GK. 2002. Studies on the antioxidant activity of pomegranate peel and seed extracts using in vitro models. Journal of Agricultural and Food Chemistry, 50: 81-86.

Singleton VL, Rossi JA. 1965. Colorimetry of total phenolics with phosphomolybdic-phosphotungstic acid reagents. American journal of Enology and Viticulture, 16(3): 144-158.

Tahmasebi-Boldaji R, Hatamipour MS, Khanahmadi M, Sadeh P, Najafipour I. 2019. Ultrasound-assisted packed-bed extraction of hypericin from Hypericum perforatum $L$. and optimization by response surface methodology. Ultrasonics sonochemistry, 57: 89-97.

Teixeira A, Baenas N, Dominguez-Perles R, Barros A, Rosa E, Moreno D, Garcia-Viguera C. 2014. Natural bioactive compounds from winery by-products as health promoters: a review. International journal of molecular sciences, 15(9): 15638-15678. 